\title{
Goran Kardaš
}

\section{Sadržaj, metoda i intencija prikaza Buddhina učenja u terminima kanonske abhidharme}

\begin{abstract}
Sažetak
Članak istražuje tip diskursa tzv. kanonske abhidharme kao najranije sustavne metode izlaganja Buddhina učenja. Lociraju se neke kanonske sūtre (Buddhini govori) koje su mogle poslužiti kao doktrinarno ishodište za oblikovanje sustava abhidharme kao i njezine metode koja se mogla korijeniti u Buddhinu razlikovanju između direktnog (nītattha) i indirektnog (neyyattha) tipa diskursa. U nastavku članka analizira se sadržaj i metoda prezentacije kanonske abhidharme buddhističke škole theravāda u djelima Dhammasaṃaṇi $i$ Abhidhammatthasangaha $u$ kojima je dosljedno provedena analiza zbilje na elementarne psiho-fizičke datosti (dharme). Potom se ukazuje na to da takva analiza zbilje u kanonskoj abhidharmi izbjegava ontološko pitanje o egzistencijalnom statusu dharmi koje valja shvatiti kao fenomenološki opis elementarnih psiho-fizičkih funkcija koje oblikuju iskustvo, odnosno »tipove "svijesti (citta). Članak završava pokušajem određenja intencije formiranja sustava abhidharme.
\end{abstract}

\section{Ključne riječi}

abhidharma, Buddha, dharma, fenomenologija iskustva, theravāda, tipovi svijesti

Termin abhidharma ${ }^{1}$ pojavljuje se u buddhističkoj tradiciji u dva osnovna značenja: 1. kao naziv za tekstove koji čine posljednji dio ranobuddhističkog kanona (abhidharma kao tekst, Abhidharma pițaka); 2. kao naziv za specifičnu metodu izlaganja Buddhina učenja (abhidharma kao metoda).

Stoga se pitanje podrijetla abhidharme može promatrati iz dviju različitih perspektiva: iz historijske perspektive oblikovanja samih tekstova i iz perspektive unutarnje intencije, tj. razloga i motiva koji su doveli do oblikovanja specifičnih tema i njihovih tretiranja u tim tekstovima. Mi ćemo pristupiti razmatranju abhidharme primarno iz ove druge perspektive. ${ }^{2}$

\section{1}

Kada se pridaje imenicama, prefiks abhi- nosi značenje »viši«, »nad«, »dodatan«, ali se može pojaviti i u značenju »što se odnosi na«, »u pogledu«, pa su moguća barem dva prijevoda termina abhidharma: »viša dharma« $\mathrm{i}$ »što se odnosi na dharmu«. Usp. Isaline Blew Horner, "Abhidhamma Abhivinaya in the first two of the Pāli Canon«, Indian Historical Quarterly 17 (1941) 3, str. 291-310.

2

Što se tiče historije nastanka kanonskih tekstova abhidharme, jedino što je izvjesno jest da su nastajali u stoljećima nakon Budd- hine smrti i da recenzije koje posjedujemo (pālijska škola theravāda i kineski prijevod škole sarvāstivāda) ukazuju na to da su ti tekstovi nastajali u vrijeme kada više nije postojala jedinstvena buddhistička zajednica (sangha). Usp. v. o tome u: Étienne Lamotte, History of Indian Buddhism, Université Catholique de Louvain, Louvain 1988., str. 179191, 272-292, 517-548; Erich Frauwallner, Studies in Abhidharma literature and the origins of Buddhist philosophical systems, preveo Sophie Francis Kidd, State University Press, New York 1995., str. 1-117; Hirakawa Akira, History of Indian Buddhism. From 
Općenito govoreći, jezgru tekstova abhidharme čine pobrojavanje, klasificiranje (dovođenje u su-odnos) i definiranje onih Buddhinih učenja, iskaza itd. koji su u kanonskim sūtrama (Buddhinim govorima) objelodanjeni jezikom i kontekstom koji je »primjeren stvarnosti« (yathābhütam), tj na neposredan način (nittattha), za razliku od onih učenja, iskaza itd. čije se pravo značenje tek treba izvesti (iz metafore, poredbe, aluzije, svakodnevnog govora i sl., neyyattha, usp. A. I. 60). ${ }^{3}$ Tako Abhidharma kani okupiti, jezično pročistiti i »mapirati« nesustavna i »razbacana« Buddhina učenja iz sūtri i prikazati njihov međuodnos prema različitim metodama klasificiranja, oblikujući tako totalitet ili su-stav buddhističke doktrine u terminima lišenim svake subjektivnosti, nejasnoće ili proizvoljnosti.

Nema sumnje da je takav tip izlaganja učenja djelomično prisutan i u kanonskim sūtrama, često u situacijama kada najumniji Buddhini učenici (Śāriputra prije svih) u prisutnosti učitelja i najuže redovničke zajednice kazuju 4 ili recitiraju doktrinarne »liste« koje će kasnije biti uvrštene i proširene u sustavu abhidharme. Tako npr. dvije posljednje sūtre iz zbirke Dìgha-nikāya, Sangītisutta (33) i Dasuttara-sutta (34), ${ }^{5}$ očigledno predstavljaju »prototip« kasnije abhidharme, ${ }^{6}$ kako po temi, tako i po metodi izlaganja. ${ }^{7}$

U nekim »rezimirajućim« sūtrama, Buddha također sažima učenje na način koji je očito bio ishodišan za kasnije razvrstavanje i usustavljanje kategorija abhidharme. Najpoznatija od tih lista skupina je od trideset sedam »udova probuđenja « (bodhipakkhiya dhamma) ${ }^{8}$ koje Buddha navodi, između ostaloga, i u slavnoj Mahāparinibbāna-sutti:

»Ta učenja, o kojima ja imam neposredno znanje i o kojima sam vas poučavao, njih bi trebali obuhvatno učiti, kultivirati, razvijati i učestalo prakticirati.« (D. 16) ${ }^{9}$

To su: četiri temelja pažnje (satipatțhana), ${ }^{10}$ četiri temelja moći (iddhipāda), ${ }^{11}$ četiri ispravna napora (sammappadhāna), ${ }^{12}$ pet sposobnosti (indriya) ${ }^{13}$ pet snaga (bala), ${ }^{14}$ sedam faktora probuđenja (bojjhanga) ${ }^{15}$ i osmerostruki plemeniti put (ariyamagga). ${ }^{16}$

Konačno, različita izlaganja totaliteta fenomena iskustva (dhamma) koja se »skrivaju « iza tehničkih termina poput pañcakhandha, ${ }^{17}$ àyatana,${ }^{18}$ dhātu,${ }^{19}$ paticca-samuppāda, ${ }^{20}$ itd., na nebrojenim mjestima Sutta-pitake ${ }^{21}$ predstavljaju ne samo metodološko polazište nego u dobroj mjeri i gotov doktrinarni materijal za izgradnju sustava abhidharme. ${ }^{22}$

Ako pobliže razmotrimo npr. trideset sedam udova probuđenja i elemente koje obuhvaćaju, ${ }^{23}$ primijetit ćemo još jedno metodološko obilježje koje je razvijeno u abhidharmi, naime da se »isti« elementi (dhamma) pojavljuju u različitim klasifikacijama i pod različitim naslovima što znači, prevedeno na fenomenološki jezik, da se određeni tipovi svjesnoga doživljaja ili događaja mogu javiti pod različitim (iskustvenim) okolnostima, tj. da mogu vršiti višestruku funkciju u iskustvenom toku. Dolazi li u tim promjenama funkcije određene dhamme i do razlike u njezinoj »doživljajnosti«, pitanje je koje neposredno zadire u problem »vlastite prirode « $(s a b h \bar{a} v a)$ pojedine dhamme, što će postati središnjim prijeporom postkanonske buddhističke filozofije.

Naveli smo nekoliko primjera da bismo ukazali na činjenicu da je »žanr« abhidharme u veoma razvijenom obliku prisutan već u kanonskim sūtrama. Doista, najstariji tekstovi abhidharme (Dharmaskandha sarvāstivādinske, Puggalapaññatti i Vibhañga pālijske abhidharme) još uvijek metodološki slijede analizu totaliteta iskustva preuzetu iz Sutta-pitake na khandhe, ayyatane, dhātue, trideset sedam udova probuđenja itd. I tek će se u srednjem razdoblju oblikovanja Abhidhamma pițake dovršiti konačna analiza iskustva na elemen- 
tarne tipove (dhamma) dodatnim raščlanjenjem navedenih skupina odnosno totalističkih »formula« egzistencije.

Dhammasamgani, prva, iako u cjelini ne i najstarija, knjiga pālijske Abhidhamma-pițke, tako više ne govori o āyatanama, khandhama itd., nego započinje tzv. »matricama« (mâtikā), svojevrsnim tabularnim analitičkim sadržajem u

Śākyamuni to Early Mahāyāna, University of Hawaii Press, Honolulu 1990., str. 69-139. 3

$\mathrm{A}=$ Añguttara-nikāya, 5 sv., Richard Morris, Edmund Hardy (ur.), Pāli Text Society, London 1885.-1900., pretisak 1961.

U Sutta-pițaki gdjekad se javlja složenica abhidhammakathā (»kazivanje o abhidhammi«, možda u smislu razgovora o doktrini (Dhamma) na način abhidhamme, tj. na način koji je lišen figurativnog iskaza, npr. M I. $214[\mathrm{M}=$ Majjhima-nikāya, 3 sv., Vilhelm Trenckner, Robert Chalmers (ur.), Pāli Text Society, London 1888.-1899., pretisak 1948.1951.]). Buddhaghosa u djelu Atțhasālinī (29), komentaru na prvu knjigu pālijske $A b$ hidhamma-pitake, Dhammasamgaṇi, kaže da redovnici koji znaju abhidhammu (abhidhammikabhikkhu) jesu »kazivatelji učenja « (dhammakathika), dok ostali, iako (isto) kazuju učenje, to nisu. Bit će da su se među drugim redovnicima ovi isticali svojim istaknutim umnim sposobnostima zahvaljujući kojima su Buddhino učenje mogli razumjeti neposredno, bez pomoći metafora, poredaba i iskaza razumljivih »običnome puku«(putthujana).

Thomas W. Rhys Davids, Joseph E. Carpenter, Dīgha-nikāya. 3 vols., Pāli Text Society, London 1890-1911., sūtre 33-34.

T. W. Rhys Davids davno je primijetio da te dvije sūtre po svemu pripadaju žanru $a b$ hidharme prije negoli općem diskursu Sutta-pitake zbog odsutnosti naracije i krajnje katehističke naravi tekstova. Štoviše, »sve što znamo jest da svaka od njih oblikuje svojevrsni tematski indeks doktrina raspršenih kroz Četiri Nikāye«. Usp. Thomas W. Rhys Davids, Caroline A. F. Rhys Davids, Dialogues of the Buddha. Pt. II, Oxford University Press, London 1921., str. 199. L. S. Cousins smatra da je takav tip kazivanja (i poučavanja) učenja bio karakterističan u krugu najbližih Buddhinih učenika koji su nakon njegove smrti samo nastavili započeti posao metodološkog usavršavanja takvog tipa izlaganja doktrine. Usp. Lance Selwyn Cousins, »Pāli oral literature«, u: Philip Denwood, Alexander Piatigorsky (ur.), Buddhist studies: ancient and modern, Curzon Press, London 1982., str. 3.

Štoviše, prva i vjerojatno najstarija knjiga $a b$ hidharme škole sarvāstivāda, Sañgītipāryaya, predstavlja upravo komentar na Sañīti sūtru $\mathrm{u}$ recenziji te škole (Sañgitiparyāya-sūtra), što tu i slične sūtre svrstava u prijelazno razdoblje između Sutta-pițake (Sütra àgame) i Abhidhamma-pitake (Abhidharma-pițake). Knjiga daje objašnjenja i definicije svih ključnih sadržaja osnovnoga teksta. Usp. Sakurabe Hajime, »Abhidharma«, u: Takeuchi Yoshinori, Jan van Bragt (ur.), Buddhist Spirituality: Indian, Southeast Asian, Tibetan and Early Chinese, Crossroad Publishing, New York 1993., str. 68; H. Akira, History of Indian Buddhism, str. 131. A. K. Warder mišljenja je da je to »najprimitivniji tekst abhidharme« koji posjedujemo. Usp. Anthony. K. Warder, Indian Buddhism, Motilal Banarsidass, Delhi 2008., str. 212-213.

8

Trideset i sedam udova probuđenja prema Bronkhorstu predstavljaju možda i najraniju »listu« elemenata iskustva ili elementarnih (iskustvenih) događaja (dhamma, dharma) koji se u razvijenoj pālijskoj abhidhammi nazivaju skupnim imenom "matrica" (mātikā, v. tekst dolje) i koji tako čine osnovu za sva kasnija djela te vrste. Usp. Johannes Bronkhorst, "Dharma and Abhidharma«, Bulletin of the School of Oriental and African Studies 48 (1985) 2, str. 305-320, str. 318. doi: https:// doi.org/10.1017/s0041977x00033371.

$\mathrm{D}=$ Dīgha-nikāya, 3 sv., Thomas W. Rhys Davids, Joseph E. Carpenter (ur.), Pāli Text Society, London 1890.-1911.

10

Taj silno važan aspekt Buddhina praktičkog učenja detaljno je razrađen $\mathrm{i}$ objašnjen $\mathrm{u}$ Mahāsatipatțhāna-sutti (D. 22): »Redovnici ovaj put (način) je jedini put (način) za pročišćenje bića, za prelaženje onkraj bijede i jada, za poništenje patnje i utučenosti, za stjecanje metode, za iskustvo ugasnuća, naime četiri temelja pažnje. Koja su to četiri? U toj vezi, redovnici, redovnik živi s obzirom na tijelo (kāya) motreći tijelo, odlučno (ātāpin), svjesno (sampajāna), pažljivo (satimat), poništivši žudnju i odbojnost (dauramanasya) prema svijetu (...).« Identična formulacija daje se za osjećaj (»s obzirom na osjećaj«, vedanā), misao (»s obzirom na misao/svijest «, citta) i »elemente iskustva« (»s obzirom na elemente iskustva«, dhammā). Prema daljnjem tekstu, dhammā (plural) ovdje se može shvatiti u abhidharmičkom smislu totaliteta fenomena na koje se fenomenološki može "rastaviti« odnosno analizirati iskustvo. Rezimirano, re- 
kojem se pobrajaju dhamme kao i metodologija njihova razmatranja, a koje onda postaju predmetom »definiranja « u daljnjem tekstu. Sve dhamme grupirane su u stotinu dvojki ( $d u k a)$ i dvadeset dvije trojke (tika). ${ }^{24}$ Postoji nadalje šest dvojki koje imaju zajednički »faktor«, hetu (»korijen«, uzrok) i koje su stoga stavljene u veće skupine koje se nazivaju »grozdovima« (gocchaka) i kojih ima sveukupno deset. Pored abhidhamma mātikā postoji i lista od četrdeset dvije kategorije dhamma pod zajedničkim nazivom suttantika duka $m a \overline{t i k} \bar{a}$ koja se sastoji od dvojki koje imaju neposredno podrijetlo u Suttapitaki.

Metodologija koja je upotrijebljena za prikaz funkcija ili »položaja« pojedinih dhammi u totalitetu iskustva u tome je djelu silno složena i raznovrsna i očita je nakana bila oblikovati svojevrsnu mrežu »događaja« kojom se želi iscrpsti mogućnosti iskustva promatranog pod vidom njegovih najelementarnijih (dhammičkih) svojstava, tj. »onakvog kako uistinu biva« (yathābhūta). Međutim, cijela dhammička struktura iskustva unutar theravādske škole dovršena je u pojedinostima tek u postkanonskoj pālijskoj komentatorskoj tradiciji.

Ukratko, Dhammasamgaṇi sastoji se od četiriju velikih cjelina ili »podjela« (kanda): 1. Cittuppāda kaṇda gdje se dhamme razlažu u terminima svijesti (citta) i svjesnih sadržaja; 2. Rüpa kaṇda ili razlaganje dhamma u terminima tjelesnosti/tvarnosti (rüpa); 3. Nikkhepa kanda i 4. Atthakathā kanda. Kako se treća i četvrta cjelina bave sumiranjem analitičkih iskaza (nikkhepa) odnosno dodatnim objašnjenjima (aț̣hakathā) pojedinih sadržaja prethodnih cjelina, tako prve dvije kande predstavljaju jezgru theravādske abhidhamme u njezinom »analitičkom« aspektu tj. kao raščlanjivanje i definiranje »elemenata iskustva« (dhamma).

Cittuppāda kaṇda najopćenitije razlaže iskustvo primarno pod vidom prve tika matike (kusala tika) na: 1. povoljne fenomene (kusala dhammā); 2. nepovoljne fenomene (akusala dhammāa); 3. »neutralne « fenomene, tj. one koje se ne može klasificirati ni pod povoljne ni pod nepovoljne (abyākatā dhammāa). Nadalje, povoljni fenomeni prikazuju se u odnosu prema različitim područjima egzistencije - povoljne dhamme s obzirom na područje osjetilnosti ( $k \bar{a} m a$ dhātu), područje oblikovanog ili istančane tvarnosti (rūpa-dhātu), područje neoblikovanog ili lišenog tvarnosti (arūpa-dhātu), zatim povoljne dhamme koje vode trima stadijima egzistencije u odgovarajućim područjima, te povoljne dhamme koje vode oslobođenju od triju područja egzistencije. Povoljne dhamme s obzirom na područje osjetilnosti dalje se razlažu u osam kategorija, a ove opet obuhvaćaju tri odjeljka, naime odjeljak odredbe dhamma, odjeljak koji sadrži grupiranja, klasifikacije i pobrojavanje dhamma i odjeljak o praznini (suññatā). Povoljne dhamme s obzirom na područje oblikovanog podudarne su zapravo s meditativnim područjem rüpa-jhāne (neoblikovano zadubljenje). To se područje obrađuje pod pet glavnih naslova: kasina jhāna (stupanj zadubljenja koji je rezultat usredotočivanja na odgovarajući meditativni »predmet« - kasinga ${ }^{25}$ abhibhāyatana jhāna (stupanj zadubljenja koji je rezultat ovladavanja predmetom zadubljenja), vimokkha jhāna (stupanj mentalnog zadubljenja koji je rezultat oslobođenja od svih zaprjeka - nivvarana), brahmavihāra jhāna (stupanj mentalnog zadubljenja koji je rezultat razvijanja sućuti, radosti, smirenosti itd.) i asubha jhāna (stupanj zadubljenja koji je rezultat intenzivne sabranosti na prljavštinu/nečistoću mrtvoga tijela). Povoljne dhamme s obzirom na područje neoblikovanog podudarne su, dakako, $\mathrm{s}$ četiri meditativna područja arūpa jhāne (neoblikovano zadubljenje), tj. područje beskonačnog prostora (ākāsānañcāyatana), područje beskonačne svi- 
jesti (viñ̃̃ānañcāyatana), područje ni-čega (ākiñcañ̃̃āyatana) i područje ni zamjedbe ni ne-zamjedbe (n'evasaññānāsañ̃āayatana). ${ }^{26}$ Povoljne dhamme koje vode trima stadijima egzistencije u odgovarajućim područjima analizirane su u tri osnovna tipa - niži razred povoljne svijesti, srednji razred povoljne svijesti i viši razred povoljne svijesti. Povoljna svijest $u$ ovoj analizi sagledava se iz perspektive nižih, srednjih ili viših učinaka u smislu rođenja u nižem,

dovnik živi s obzirom na elemente iskustva motreći elemente iskustva s obzirom na pe zaprjeka (nivvarana): usmjerenost prema ugodi (kāmacchandas), zlonamjernost (vyāpāda), tupost (thinamiddha), briga (uddhaccakukkucca) i neodlučnost/sumnjičavost (vicikicchā). Redovnik također motri elemente iskustva s obzirom na »pet nakupina prianjanja« (upādānakhandha), s obzirom na "šest unutarnjih i vanjskih osnova osjetilnosti « $(=12$ ayatana), s obzirom na sedam »udova probuđenja (bojjhañga) i s obzirom na četiri »plemenite istine« (ariya-sacca).

11

Ovi se pojavljuju u nekoliko kratkih kanonskih formula (npr. D. 3. 221): »Redovnik razvija temelj moći koja je poduprta silama napora za usredotočenje volje (chandas), misli (citta), snage/“energije' (viriya) i istraživanja (mīmāmsāa $). \ll$

12

Ovi obuhvaćaju napore koji: 1 . dovode do pojavljivanja fenomena (iskustva, dhamma) koji se prije nisu pojavili; 2. odvraćaju od fenomena koji su se pojavili; 3. sprječavaju u budućnosti pojavljivanje fenomena koji su spriječeni/obustavljeni; 4. usavršavaju razvijanje fenomena koji su se pojavili. Prvi i četvrti napor tiču se očito »povoljnih fenomena« (kusala dhamma), a drugi i treći nepovoljnih fenomena (akusala dhamma). Svi ti napori fenomenološki su sazdani od volje (chandas), iniciranja i uvježbavanja bodrosti/energije (viriya) i primjene i uvježbavanja misli/svijesti (citta) za postizanje odgovarajućih, gore navedenih postignuća; usp. detaljnije o tome M. III 251; D. 2. 312.

13

Pet sposobnosti (indriya): vjera/uvjerenost (saddhā), bodrost/energija (viriya), pažnja (sati), sabranost (samādhi) i mudrost/razumijevanje (paññā). Usp. S. V. 268. [S = Samyutta-nikāya, 5 sv., M. Léon Feer (ur.), Pāli Text Society, London 1884.-1898., pretisak 1960.]

14

Pet snaga (bala) identično je petima sposobnostima. Buddhaghosa u komentaru na Dhammasaṃaṇi, Atțhasālin̄̄ (124), objašnjava da je razlika između tih pet sposobnosti i pet snaga u stupnju razvijenosti: kada je odgovarajuća sposobnost čvrsta i neuzdrmana, ona postaje »snaga«. Usp. A. K. Warder, Indian Buddhism, str. 92.
15

Sedam faktora probuđenja: pažnja (sati), razlučivanje fenomena iskustva (dhammavica$y a$ ), bodrost/energija (viriva), radost (piti), pouzdanje (abhippasāda), sabranost (samādhi) i neuznemirenost/»ravnodušnost« (upekkhā). Usp. npr. D. 2. 251.

16

Ispravan (samyac) nazor (ditthi), namjera/ intencija (sankappa), govor (vach), djelovanje (kammanta), način življenja (ājīva), napor (vāyāma), pažnja (sati) i sabranost (sa$m \bar{a} d h i)$.

17

»Pet elemenata«: svijest (viñ̃̃ana), »karmičke« sastavnice koje oblikuju tipove svijesti (sankhārā), osjećaj ili osjetnost (vedanā), zamjedba (sañ̃̃a) i tvarni oblik (rūpa). Kauzalni odnos tih pet elemenata generira ono što se naziva svjesnim bićem ili, Buddhinom terminologijom, »tokom bivanja« (bhavasota).

18

»Područja osjetilnosti«: šest osjetila i njihova osjetilna područja (oko-oblik, nos-njušni predmet/miris itd.)

19

»Osnove«: šest osjetila, šest osjetilnih predmeta i šest odgovarajućih osjetilnih svijeti (oko-oblik-vidna svijest, nos-njušni predmet/miris-njušna svijest itd.)

20

"Su-nastajanje u zavisnosti«, središnji Buddhin nauk o uvjetovanosti svih fenomena.

21

Posebno u nizu sutti koje se skupno nazivaju vibhanga (»razdioba«, »analitika«). Usp. npr. »Vibhañgavagga«, u: Majjhima-nikāye, Vilhelm Trenckner, Robert Chalmers (ur.), Pāli Text Society, London 1888.-1899.

22

Prema Buddhaghosi zbirno ime za sve te dharme je abhidharma utoliko što one "nadmašuju i razlikuju se od Dhamme [tj. figurativnog, metaforičkog, 'nepreciznog', itd. izlaganja učenja u sūtrama]«. Usp. Karl H. Potter, Encyclopedia of Indian Philosophies Vol. VII. Abhidharma Buddhism to 150 A.D., Motilal Banarsidass, Delhi 2011., str. 83. To »nadmašivanje «, međutim, ne tiče se doktrinarnog sadržaja, nego prije istančanije metodologije njegova organiziranja i prezentiranja. Takav način ili tip izlaganja stoga predstavlja ab- 
srednjem i višem području egzistencije »u budućnosti«, što se fenomenološki ogleda u odlikama ( $\mathrm{tj}$. snazi ili slabosti) četiriju dominantnih mentalnih »čimbenika« (ili »sadržaja svijesti«, cetasika) koji se pojavljuju uz povoljnu svijest (kusala citta). To su žudnja, napor, misao i analitičko istraživanje. Konačno, povoljne dhamme koje vode oslobođenju od triju područja egzistencije predstavlja tzv. »transcendentalna povoljna svijest« (lokuttara kusala citta) koja je povezana sa »znanjem Puta« (magga ñāna), odnosno metodom koja bez ostatka dokida bivanje u sva tri područja egzistencije. Tom se metodom konačno dokidaju sva izvorišta patnje $(d u k k h a)$ i stječe se osobni neposredni uvid u konačni smisao i sadržaj svih Buddhinih učenja. Fenomenološki, prodor $\mathrm{u}$ »znanje Puta« odvija se kroz četiri završna postignuća: poništenje »ja-gledišta« (sakkāya ditți) koje automatski prati poništenje mnogih drugih nepovoljnih dhamma. To iskustvo označuje »ulazak u tok znanja Puta« (sotāpatti magga ñāna). Drugo postignuće karakterizira krajnje »slabljenje« triju korijenskih nepovoljnosti (akusala hetu, tj. odbojnost, pohlepa, obmana) i samim tim označuje daljnje poništenje mnogih drugih nepovoljnih dhamma. To iskustvo označuje »znanje Puta onih koji se vraćaju još (samo) jednom《 (sakadāgāmì magga ñāna), tj. kojima predstoji još samo jedno rođenje. Treće postignuće karakterizira posvemašnje iskorjenjivanje osjetilnih žudnji i zlovolje kao i svih dhamma, bilo povoljnih bilo nepovoljnih, koje vode području osjetilne egzistencije. To iskustvo označuje »znanje Puta onih koji se više ne vraćaju« (anāgāmī magga ñāna), tj. koji iskušavaju posljednje rođenje. Konačno, posljednje postignuće karakterizira cjelovita iskorijenjenost preostalih pet zaprjeka, tj. žudnje za područjem oblikovanog ( $r \bar{u} p a-)$, neoblikovanog (arūpa-), samoljublja, nemira i neznanja ili, bolje kazano, njihovih preostalih tragova u iskustvu. Kako to postignuće karakterizira potpunu ishlapjelost "pogonskog goriva« (kamma, sankhārā itd.) koje oblikuje khandhe, kako s obzirom na prošlost, tako i s obzirom na budućnost, to iskustvo istovjetno je iskustvu nibbāne. Stoga ono označuje »znanje puta arahata ( arahatta magga $\tilde{n} \bar{a} n a$ ) koje se u Buddhinim govorima često iskazuje sintagmom: »Završen je put, dokončano je bivanje«. Kroz ta četiri stadija »znanja Puta« oblikuje se i konačno ostvaruje »prodiruće znanje« u krunsko Buddhino učenje o »Četiri plemenite istine« o patnji.

Rüpa kaṇda pobrojava, klasificira i analizira tvarni (rüpa) aspekt iskustva u njegovoj elementarnoj pojavnosti (dhamma) prema cijelom nizu metodoloških načela. Osnovna je podjela svih tvarnih aspekata iskustva u jedanaest razreda: 1. Veliki elementi (mahābhüta), tj. zemlja, voda, vatra, zrak, koji se smatraju temeljnim konstituensima tvarnosti i koji ulaze u sastav svih drugih, stoga izvedenih (upādāya) tvarnih fenomena; 2. osjetilni tvarni fenomeni (pasādarūpa), tj. osjetnost oka, uha, nosa, jezika i tijela (»kože«). Ove se shvaćaju kao »fine « tvari koje prožimaju odgovarajuće osjetilne organe $\mathrm{i}$ kroz koje se događa transfer osjetilnih podražaja u područje svijesti, pri čemu "grubi« osjetilni organi (oko itd.) služe kao »organska« podrška toga procesa; 3. objektivni tvarni fenomeni ili »objektivna područja tvarne osjetilnosti« (gocararüpa), tj. vidni oblik, zvuk, miris, okus i opipnost; 4. tvarni fenomeni spolnosti (bhavarūpa), tj. ženskost i muškost koji se shvaćaju kao sposobnosti koje iskazuju obilježja ženskog i muškog spola; 5. tvarni fenomen srca (hadayarūpa) shvaća se kao »srce-osnova« (hadayavatthu) koja predstavlja »tvarnu podršku « područja razuma (manodhātu), odnosno područja »razumske svijesti« (manoviñ̃ānadhātu); 6. tvarni fenomen životnosti (jīvitarūpa), tj. životna sposobnost (jīvitindriya) čija je karakteristika održavanje supostojećih tvarnih oblika u svakom trenutku njihove prisutnosti; kroz nju se ovi 
očituju; 7. tvarni fenomen hrane (āhārarūpa), tj. »jestiva« hrana (kabaḷikāara) koja se shvaća kao hranjiva tvar sadržana u jestivoj hrani; 8. ograničujući tvarni element (paricchedarūpa), tj. element ili područje prostora $(\bar{a} k \bar{a} s \bar{a} d h \bar{a} t u)$ čija je karakteristika odvajanje i razgraničavanje tvarnih fenomena, čime ovi postaju uočljivi i razaznati. Međutim, prostor se ovdje ne shvaća u protežnom smislu nego fenomenološki, kao područje »iskustvene praznine« koja je podloga ili potpora distinktivnom svjesnom zapažanju (tvarnog aspekta) fenomena; 9. tvarni fenomen priopćavanja (viññattirūpa), tj. tjelesno (kāya-) i govorno (vaci-) priopćavanje (viñnatti) čija je osnovna funkcija iskazivanje intencije i kao takvi shvaćaju se kao uzrok tjelesnih i verbalnih izražavanja; 10. promjenjivi tvarni fenomeni (vikārarūpa), tj. lakoća (lahutā, u smislu ne-tromosti tvarnoga aspekta iskustva), rastezljivost (mudutā, u smislu nekrutosti tvarnog aspekta iskustva), upotrebljivost/izvedivost (kammaññatā, $\mathrm{u}$ smislu ne-slabosti, ne-nedjelatnosti tvarnog aspekta iskustva) i već navedena dva tipa tvarnog fenomena priopćavanja (tjelesno i govorno); 11. karakteristike tvarnih fenomena (lakkhanarūpa), tj. proizvođenje (upacaya), trajanje (santati), opadanje (jarātā) i netrajnost (aniccatā).

Kako je analiza iskustva na njegove elementarne tipove (dhamma) u Abidhamma-pițaki s metodološke strane bila silno složena i zapravo nedovršena, theravādska je tradicija otprilike nakon vremena Buddhaghose (5. st.), čiji komentari na pālijski kanon predstavljaju završnu riječ theravādske doktrinarne pozicije, proizvela nekoliko priručnika abhidhamme u kojima se na sažeti način i jednostavnijom metodologijom nastojala predstaviti jezgra učenja. Ti su priručnici vremenom posve zamijenili opsežne i često neprohodne knjige Abhidhamma pitake i oni do danas u zemljama theravādskog buddhizma (Šri Lanka, Myanmar, Tajland, Laos, Kambodža) služe kao osnovni tekstovi za izučavanje (kanonske) abhidhamme. Najpoznatiji i najcjenjeniji od tih priručnika je Abhidhammattha sangaha (»Sažeti prikaz abhidhamme«) koji se pripisuje »nekom« Anuruddhi (negdje između 10. i 12. st.).

hidharmički sadržaj unutar Sutta-pițake. Usp. Peter D. Santina, The Tree of Enlightenment, Chico Dharma Study Foundation, 1997., str. 388.

23

Usp. bilješke uz odgovarajuće skupine.

24

Primjer dvojke: (hetu duka) - 1. dhamme koje su (korijenski) uzroci fenomena (hetu dhammā); 2. dhamme koje nisu (korijenski) uzroci fenomena (na hetu dhammā). Primjer trojke: (vedanā tika) - 1. dhamme koje su združene s ugodnim osjećajem (sukhāya vedanāya sampayutta dhammā); 2. dhamme koje su združene s neugodnim osjećajem (dukkhāya vedanāya sampayutta dhammā); 3. dhamme koje su združene s osjećajem koji nije ni ugodan ni neugodan (adukkhaasukhāya vedanāya sampayutta dhammā).

25

Kasina se odnosi na »predmet« koji u preliminarnim meditacijskim stadijima ima funkciju uvježbavanja usredotočenja. Pālijska tradicija govori o deset takvih predmeta (zemlja, voda, zrak, plavo, žuto itd.). Na primjer, praktikant postavlja obojeni disk ispred sebe i upravlja svoju pažnju na njega sve dok se u svijesti ne pojavi njegova mentalna slika, tzv. "stečeni znak« (uggaha-nimitta). Usmjeravajući pažnju dalje na tu sliku, pojavljuje se savršeno jasna i postojana »protu-slika« (patibhāga-nimitta) i s tim događajem praktikant stupa na prag oblikovanog zadubljenja (rūpa-jhāna). Ta praksa razrađena je do detalja u Visuddhimaggi Buddhaghose (knjige 4 i 5). Usp. također, Bhikkhu Bodhi, Abhidhammattha sangaha: A Comprehensive Manual of Abhidhamma: Pāli Text, Translation \& Explanatory Guide, BPS Pariyatti Editions, Kandy 1993., str. 332-333.

26

Fenomenologiju tih meditativnih stadija zadubljenja u nas je detaljno analizirao Čedomil Veljačić, nastojeći je razjasniti iz perspektive Husserlove fenomenologije. Usp. Cedomil Veljačić, Filozofije istočnih naroda. Knj. 1, Indijska filozofija $i$ odabrani tekstovi, Nakladni zavod Matice hrvatske, Zagreb 1982.; Čedomil Veljačić, Razmeđa azijskih filozofija. Knj. 1, Sveučilišna naklada Liber, Zagreb 1978.; Čedomil Veljačić, Philosophia Perennis. Sv. 2, Demetra, Zagreb 2004. 
Dio koji odgovara Cittuppāda kaṇdi knjige Dhammasaṃaṇi u tom je priručniku razdijeljen u dva osnovna dijela: 1. odjeljak/sažetak o svijesti (cittasangaha) i 2. odjeljak/sažetak o mentalnim fenomenima (cetasikasangaha). ${ }^{27}$

Kao osnovni element iskustva koji »obasjava« sva moguća predmetna područja, tj. događanja u iskustvenom toku, svijest $(\text { citta })^{28}$ se ovdje motri pod vidom četiri osnovna područja (avacara) svoga pojavljivanja: 1. svijest osjetilnog područja (kāmāvacara), 2. svijest oblikovnog područja (rūpāvacara), 3. svijest neoblikovnog područja (arūpāvacara) i 4. svijest »nadsvjetovnog» područja (lokuttarāvacara). Četiri su moguće prirode ili »vrste« (jāti) svijesti koje se mogu javiti u tim područjima: 1. nepovoljna (akusala), 2. povoljna (kusala), 3. »rezultirajuća« (vipāka) i 4. »funkcionalna« (kriyā ili kiriya) svijest (citta). Prve dvije vrste svijesti konstituiraju voljnu djelatnost (kamma), treća se odnosi na vrste svijesti koje nastaju dozrijevanjem prve dvije vrste svijesti (vipāka-citta u smislu kamma-vipāka), dok se u četvrtom tipu svijesti reflektiraju karmički neodređene djelatnosti, tj. one koje ne pobuđuju nikakve karmičke rezultate (posljedice).

Budući da je metodologija predstavljanja svih područja svijesti u tom priručniku daleko prohodnija nego što je slučaj s Dhammasaṃaṇi, možemo sažeto izložiti cijelu klasifikaciju, navodeći pri tome i primjere nekih »definicija« uz dodatna razjašnjenja.

Svijesti osjetilnog područja (kāmāvacara cittāni) klasificiraju se u tri osnovne skupine: 1. nepovoljne svijesti (akusalacittāni), 2. svijesti lišene korijena $\left(\right.$ ahetukacittāni $\left.{ }^{29}\right)$ i 3. »blistave« svijesti (sobhanacittāni).

Nepovoljne svijesti (akusalacittāni) dalje se klasificiraju na: a) svijesti ukorijenjene u pohlepi (lobhamūlacittāni), ${ }^{30}$ b) svijesti ukorijenjene u mržnji $(\text { dosamūlacittāni })^{31} \mathrm{i}$ c) svijesti ukorijenjene u obmani (mohamūlacittāni). ${ }^{32}$

Svijesti lišene korijena (ahetukacittāni) klasificiraju se na: a) rezultirajuće nepovoljne svijesti (akusalavipākacittāni), ${ }^{33}$ b) rezultirajuće povoljne lišene korijena svijesti (kusalavipākahetukacittāni) ${ }^{34} \mathrm{i}$ c) lišene korijena funkcionalne svijesti (ahetukakiriyacittāni). ${ }^{35}$

Blistave svijesti (sobhanacittāni) jesu sve one koje preostaju kada se isključe nepovoljne i lišene korijena svijesti (pāpāhetukamuttāni). Nazivaju se blistavima zato što ih okružuju »blistavi« (lijepi, povoljni i sl.) mentalni faktori ili fenomeni (cetasika). Dalje se klasificiraju na: a) povoljne svijesti osjetilnog područja (kāmāvacarakusalacittāni) ${ }^{36}$ b) rezultirajuće svijesti osjetilnog područja (kāmāvacaravipākacittāni $)^{37}$ i c) funkcionalne svijesti osjetilnog područja (kāmāvacarakriyācittāni). ${ }^{38}$

Svijesti oblikovnog područja (rūpāvacaracittāni) obuhvaćaju, dakako, tipove svijesti koji se pojavljuju u kontemplativnoj shemi oblikovnog zadubljenja (rüpa-jhāna) kojim se nadilazi osjetilno područje (kāmāvacara). Dalje se klasificiraju na: a) povoljne svijesti oblikovnog područja (rūpāvacarakusalacittā $n i),{ }^{39}$ b) rezultirajuće svijesti oblikovnog područja (rūpāvacaravipākacittāni) $40 \mathrm{i}$ c) funkcionalne svijesti oblikovnog područja (rūpāvacarakriyācittāni). ${ }^{41}$

Svijesti neoblikovnog područja (arūpavacaracittāni) predstavljaju daljnje (kontemplativno) bistrenje spoznajnoga toka i shodno tome uvida u »stvari kako uistinu bivaju « (yathābhütam).

Ta se postignuća također klasificiraju prema povoljnim ( $k$ usala $){ }^{42}$ rezultirajućim (vipāka $)^{43}$ i funkcionalnim $(k r i y \bar{a})^{44}$ tipovima svijesti na tom području. Svijesti nadsvjetovnog područja (lokuttaracittāni) jesu oni tipovi svijesti koje prate proces nadilaženja (uttara) »svijeta« (loka) kojega je Buddha definirao, među inima, kao "pet sastavnica prianjanja« (pañcakkhandhupādāna). Te 
svijesti neupitno vode okončanju bivanja, poništenju svih karmičkih energija i njihovih tragova u toku bivanja te stoga dokončanju patnje ( $d u k k h a)$, neznanja (avijjā) itd., riječju, one privode tok bivanja nibbāni. Dijele se dalje na a)

27

Fenomeni iskustva koji se uvijek ili ponekad pojavljuju u svakom trenutku svjesnog ili nesvjesnog doživljaja, »sateliti svijesti«.

28

Ārammañam cintetiti cittam, »svijest je ono što 'obasjava' predmet«.

29

Ahetuka - lišen korijena, »neukorijenjen«, odnosi se na tipove svijesti koji su lišeni šest korijenskih mentalnih fenomena ili čimbenika (cetasika), tj. pohlepe (lobha), mržnje (dosa), obmane (moha) i njihovih suprotnosti (ne-pohlepe itd.).

30

Primjer: »Jedna (svijest), prožeta 'vedrim duhom'('dobrovolja'), združena s pogrešnim gledištem, nepobuđena« (somanassasahagatam dițthigatasampayuttam asankhārikam ekaim). U ovoj i sljedećoj podskupini nepovoljnih svijesti, svijest se analizira prema trima načelima: osjećaju (vedanā) koji je prati (»vedar duh«, »tmurni duh«, »ravnodušnost «/neuznemirenost, upekkhā, odbojnost, patigha), prisutnosti ili odsutnosti pogrešnih gledišta i pobuđenosti (tjelesna, verbalna ili mentalna) ili nepobuđenosti svijesti. Sveukupno, ova podvrsta nepovoljnih svijesti broji osam osnovnih tipova svijesti.

31

Primjer: »Jedna (svijest), prožeta 'tmurnim duhom' ('zlovolja'), združena s odbojnošću, pobuđena« (domanassasahagatam patighasampayuttaim sasankhārikam ekam). Sveukupno, dva osnovna tipa svijesti.

32

Primjer: »Jedna (svijest), prožeta ravnodušnošću, združena sa sumnjom« (upekkhāsahagatai் vicikicchāsampayuttam ekai்). Sveukupno, dva osnovna tipa svijesti. Tako nepovoljne svijesti broje dvanaest osnovnih tipova.

33

Vidna, slušna, mirisna i okusna svijest prožeta ravnodušnošću (upekkhāsahagata), opipna (»tjelesna«) svijest (kāyaviñ̃̄āna) prožeta boli/neugodom (dukkhasahagata), »primalačka« svijest (sampaticchanacitta) prožeta ravnodušnošću i »istraživalačka« (procesuirajuća) svijest (santīranacitta) združena ravnodušnošću. Sveukupno, sedam osnovnih tipova svijesti. Primanje i istraživanje označuju dva osnovna čina spoznajnog procesa. Kada osjetilni predmet pobudi odgovarajuću osjetilnu sposobnost najprije se pojavljuje svijest koja zahvaća ili »skreće pozornost« (ävajjana) na taj predmet. Odmah potom slijedi odgovara- juća osjetilna svijest, a u sljedećem trenutku svijest koja »prima« predmet zahvaćen osjetilnom sviješću, tj. primalačka svijest. U neposredno sljedećem činu spoznajnog procesa pojavljuje se istraživalačka (procesuirajuća) svijest koja istražuje ili ispituje predmet koji je tako primljen posredstvom primalačke svijesti. Obje te funkcije svijesti odvijaju se u okolnostima prethodećih spoznajnih činova i njihovih svojstava pa se stoga shvaćaju kao »rezultirajuće svijesti« (vipākacitta).

34

Četiri gore navedene osjetilne svijesti također prožete ravnodušnošću, opipna (tjelesna) svijest prožeta ugodom (sukhasahagata), primalačka i istraživalačka svijest također prožete ravnodušnošću i istraživalačka svijest (dodatno) prožeta »vedrim duhom《 (dobrovoljom, somanassasahagata). Sveukupno, osam osnovnih tipova svijesti. 35

»Zahvaćajuća ('pozornost skrećuća') svijest (prema) pet osjetilnih ulaza prožeta ravnodušnošću« (upekkhāsahagataim pañcadvārā vajjanacittai்...), »zahvaćajuća ('pozornost skrećuća') svijest (prema) 'razumskom' ulazu (tj. razumu kao šestom, sintetizirajućem osjetilnom području) prožeta ravnodušnošću« (manodvārāvajjanacitta...) i »svijest koja pobuđuje osmjeh prožeta vedrim duhom (dobrovoljom)《 (somanassasahagatam hasituppādacittam). Sveukupno, tri osnovna tipa svijesti. Ti tipovi svijesti ne proizvode karmičke učinke, stoga se nazivaju »funkcionalnima« (kiriya). Premda je Buddha govorio o osjetilnoj svijesti kao neposrednom rezultatu susretišta ili »dodira« (phassa) osjetilne sposobnosti i odgovarajućeg osjetilnog predmeta, theravādska abhidhamma, vidimo, dodatno je raščlanila taj proces uvodeći tzv. »pozornost skrećuću« svijest koja »privodi« ili predstavlja predmet jednom od pet osjetilnih »ulaza« (dvāra). Ta svijest nema funkcionalnu vrijednost osvješćivanja osjetilnih predmeta (gledanje, slušanje itd.), nego jednostavno skreće pozornost na njih, pobuđujući u sljedećem trenutku nastajanje odgovarajuće osjetilne svijesti. Pozornost skrećuća svijest prema razumskom ulazu (manodvāra) ima dvojaku funkciju: određivanje predmeta koji je zahvaćen osjetilnom sviješću što uključuje i njegovu diskriminaciju (razlučivanje) i njegovo »ideiranje« kada se očituje kao konkretni, razum-osviješteni (manoviñ̃̃āna) »predmeti mišljenja«, što predstavlja početak oblikovanja pojmova, ideja, koncepcija itd., koji više nisu neposredno povezani ili uvezani $u$ »fiziološke« ili prirodne osnove spoznajnog procesa. Na toj se epistemološkoj točki 
povoljne svijesti koje nadilaze »svijet« (lokuttarakusalacittāni $)^{45}$ i b) rezultirajuće svijesti koje nadilaze »svijet « (lokuttaravipākacittāni). ${ }^{46}$

Kada se zbroje svi tipovi svijesti iz svih četiriju područja, dobivamo osamdeset devet osnovnih tipova svijesti theravādske abhidhamme. Klasifikacija prema prirodi ili vrsti (jāti) svijesti daje dvanaest nepovoljnih tipova svijesti, dvadeset jedan povoljan tip svijesti, trideset šest rezultirajućih tipova svijesti i dvadeset funkcionalnih tipova svijesti, a prema području (avacara, bhümi): pedeset četiri tipa svijesti osjetilnog područja (kāmāvacara), petnaest tipova svijesti oblikovnog područja (rūpāvacara), dvanaest tipova svijesti neoblikovnog područja (arūpāvacara) i osam tipova svijesti »nadsvjetskog« područja (lokuttara).

Odjeljak o mentalnim fenomenima ili čimbenicima (cetasikasangaha) bavi se drugim tipom iskustvenih događaja motrenih iz perspektive najviše zbiljnosti $\left(\right.$ paramatthatas $\left.^{47}\right)$ ili fenomenološki, iz perspektive dalje nesvodivih elementarnih tipova iskustvenih doživljaja. Cetasike se uvijek i neizostavno pojavljuju uz odgovarajuće tipove svijesti izvodeći specifične funkcije u iskustvenom (spoznajnom) toku. Kao što se cetasike ne mogu pojaviti mimo svijesti, tako se ni svijest ne može pojaviti odvojena od cetasika. Drugim riječima, »čista svijest« je prema abhidhammi nezamisliva i puka je apstrakcija. Prvenstvo svijesti je čisto fenomenološke naravi, kao »principijelnog « kognitivnog elementa, »izljuštenog « iz bujice iskustva jedino radi analize iste, dok je in concreto »ona « uvijek uvezana u ostale kognitivne, konativne i afektivne aspekte iskustva koji konkretno oblikuju »tipove« svijesti o kojima je prethodno bilo govora. Ti se »tipovi« svijesti, dakako, u okolnostima odsutnosti nositelja kognitivnih procesa nužno shvaćaju kao funkcije osvješćivanja ili »obasjavanja« specifičnih područja (avacara, bhümi) toka bivanja. Odnos između citte i cetasika Buddhaghosa uspoređuje s kraljem i njegovom pratnjom. Iako se kaže »kralj dolazi«, kralj zapravo nikada ne dolazi sam, nego uvijek u pratnji svoje dvorske svite. ${ }^{48}$

Prema uvodnoj odredbi, cetasike nastaju zajedno sa sviješću, nestaju zajedno sa sviješću, imaju istu podršku (»predmet «) kao svijest i imaju istu osnovu kao svijest. ${ }^{49}$ Priručnik ih dijeli u sedam kategorija: 1. cetasike koje su opće (zajedničke) svim (tipovima) svijesti (sabbacittasādhārana), ${ }^{50}$ 2. cetasike koje su posebne (svojstvene samo određenim tipovima svijesti) (pakinnaka), ${ }^{51} 3$. nepovoljne cetasike (akusala ${ }^{52}$ ), 4. blistave cetasike (sobhana), ${ }^{53}$ 5. cetasike uzdržavanja (virati),${ }^{54} 6$. nemjerljive (»bezgranične«) cetasike (appamañña $)^{55}$ i 7. cetasika ne-obmane (amoha). ${ }^{56}$

Nakon pobrojavanja svih mentalnih cetasika u priručniku se u nastavku govori o načinu povezivanja (sampayoga) odgovarajućih cetasika s odgovarajućim tipovima svijesti, tj. koje se cetasike pojavljuju uz koji tip svijesti ovisno o području (avacara) njezina očitovanja, izuzev prvih sedam koje se pojavljuju uz svaki tip svijesti (sabbacittasādhāraṇa).

Theravādska abhidhamma u svojoj konačnoj izvedbi broji osamdeset devet osnovnih tipova svijesti (citta) i pedeset dva mentalna faktora (cetasika). Kada se tome pridoda dvadeset osam elementarnih osnova tvarnog aspekta iskustva $(r \bar{u} p a)^{57}$ i nibbanna ${ }^{58}$ dobije se totalni opis elementarne strukture (mogućeg) iskustva, prema toj školi, koji se dade svesti na osamdeset dva osnovna »elementa iskustva « (dhamma). ${ }^{59}$

Recenzija Abhidharma-pitake škole sarvāstivāda, barem kada je riječ o najranijim slojevima, također se usredotočuje na pobrojavanje, opisivanje i klasificiranje osnovnih elemenata iskustva »izljuštenih « iz zajedničkog nasljeđa Sutta-pițke (Sūtra-āgame). Premda u tom ranom razdoblju ne posjeduje 
posebnu »taksonomsku« knjigu nalik theravādskoj Dhammasaṃaṇi u kojoj bi se planski i sustavno izvela cijela »uzlazna« struktura iskustva raščlanjena na njezine elementarne »tipove«, najstarije knjige njihove Abhidharma-

počinju generirati nepovoljna mentalna stanja i općenito cijeli circus vitiosus iskustva. Svijest koja pobuđuje osmijeh (hasituppādacitta) jest tip svijesti svojstven »probuđenim《 svjesnim bićima (arahantima, buddhama, paccekabuddhama) kod kojih fenomeni osjetilnog područja »izazivaju smijeh«, što predstavlja "afektivni« učinak njihove razdruženosti od istih. Dakle, sveukupno, svijesti lišene korijena (ahetukacittāni) broje osamnaest osnovnih tipova svijesti.

36

Primjeri: »Jedna (svijest) prožeta 'vedrim duhom', združena sa znanjem, nepobuđena« (somanassasahagatam $\tilde{n} \bar{a} n a s a m p a y u t t a \dot{m}$ asankhärikam ekaì); »Jedna (svijest) prožeta ravnodušnošću, razdružena od znanja, pobuđena« (upekkhāsahagatam ñānavippayuttam sasankhārikam ekam). Sveukupno u ovoj podskupini, osam osnovnih tipova svijesti. "Znanje« (ñāna) ovdje se odnosi na znanje koje shvaća ili zahvaća stvari kakve jesu odnosno kako uistinu bivaju (yathābhūtam), pa se otuda može shvatiti i u smislu mentalnog faktora (cetasika) klasificiranog kao mentalni »faktor mudrosti« (pañ̃̄a-cetasika). Razdruženost od takvog znanja nije istovjetna »kardinalnom« neznanju (avijjā) koje se razvija isključivo pod vidom nepovoljnih (akusala) tipova svijesti. Prema komentarima, »razdruženost od znanja« u kontekstu povoljnih svijesti područja osjetilnosti fenomenološki označuje svijest koja je lišena dvaju nepovoljnih korijena (pohlepe i mržnje), ali ne i obmane (moha). Usp. B. Bodhi, Abhidhammattha sangaha, str. 48.

37

Identičnih osam tipova svijesti iz prethodne klasifikacije koji se ovdje, međutim, odnose na odgovarajuće rezultirajuće svijesti iz osjetilnog područja povoljnih svijesti.

38

Identičnih osam tipova svijesti iz dviju prethodnih klasifikacija koji, međutim, ne proizvode karmičke učinke, nego jednostavno izvode svoje »funkcije" ne ostavljajući (karmičke) tragove u iskustvenom toku (bhavañga, bhavasota). Ti su tipovi svijesti stoga karakteristični za arahante, buddhe i paccekabuddhe. Rezimirano, na osjetilnom području (kāmāvacara) theravādska abhidhamma broji pedeset četiri osnovna tipa svijesti (dvanaest nepovoljnih, osamnaest lišenih korijena i dvadeset četiri blistavih). S obzirom na četiri prirode ili vrste (jāti) svijesti, u ovom se području pojavljuje osam povoljnih, dvanaest nepovoljnih, dvadeset tri rezultirajućih i jedanaest funkcionalnih svijesti ( $=$ pedeset i četiri).
39

Pet tipova svijesti koje karakterizira sukcesivno reduktivno poništenje odgovarajućih mentalnih čimbenika. Tako prvi tip svijesti prate misaono zahvaćanje (vitakka), misaono »održavanje« predmeta (vicāra), radost (pīti), ugoda/»sreća« (sukha) i jedno-smjernost, tj. usredotočenost pažnje na jedan "predmet» (ekaggatā), dok u svijesti posljednjeg, petoga zadubljenja preostaje samo jedno-smjernost (ekaggatā) uz pojavljivanje ravno-dušnosti/ neuznemirenosti (upekkhā), čime se postiže čvrsto utemeljena pažnja neophodna za više stupnjeve zadubljenja. $O$ fenomenološkoj vrijednosti i prirodi tih mentalnih čimbenika, usp. B. Bodhi, Abhidhammattha sangaha, str. 56-58.

40

Pet odgovarajućih (karmički) rezultirajućih svijesti iz prethodne klasifikacije.

41

Pet odgovarajućih (karmički nerezultirajućih) funkcionalnih svijesti koje, dakako, iskušavaju arahanti kada prakticiraju oblikovno zadubljenje (rūpajhāna). Sveukupno, dakle, petnaest osnovnih tipova svijesti na području oblikovnog (rūpāvacara).

42

Povoljna svijest koja se odnosi na: osnovu beskonačnog prostora (ākāsānañcāyatana), osnovu beskonačne svijesti (viñ̃̃ānañcāyatana), osnovu ni-čega (ākiñcaññāyatana) i osnovu-ni-zamjedbe-ni-ne-zamjedbe (n'evasaññanāsaññàyatana). Sveukupno, četiri osnovna tipa svijesti. To su zapravo sukcesivna kontemplativna postignuća neoblikovnog zadubljenja (arūpajhāna). O fenomenologiji tih postignuća, usp. B. Bodhi, Abhidhammattha sangaha, str. 62-63; Č. Veljačić, Filozofije istočnih naroda. Knj. 1, str. 105-113; С̆. Veljačić, Razmeđa azijskih filozofija. Knj. 1, str. 251-258.

43

Četiri rezultirajuća tipa svijesti (vipākacittāni) istih četiriju gore navedenih kontemplativnih osnova.

44

Četiri funkcionalna tipa svijesti (kriyācittāni) navedenih kontemplativnih osnova. Sveukupno, dakle, dvanaest osnovnih tipova svijesti neoblikovnog područja.

45

»Svijest puta ulaženja u tok« (sotapāttimaggacitta), »svijest puta onoga koji se jednom vraća« (sakadāgāmīmaggacitta, tj. koji će se roditi još samo jednom), »svijest puta onoga 
pițake, Sañītiparyāya, Dharmaskandha i dijelom Dhātukāya, posve slijede tu osnovnu ideju. ${ }^{60}$

Preostaje nam da razmotrimo koja je mogla biti intencija prikaza jezgre Buddhina učenja u terminima rane abhidharme. Ono što je izvjesno jest očevidno nastojanje abhidharmīka da prodube i razbistre Buddhinu analitičku metodu (vibhajja) raščlanjivanja iskustva na određeni broj elementarnih funkcija ili »događaja« koji u svojoj suodnosnosti predstavljaju totalan opis »iskustvenih mogućnosti« egzistencije u okolnostima nepostojanja njezina ontološkog žarišta (čista svijest, duša, àtman). Dok je Buddhino »razbijanje« naivne metafizičke relacije subjekt (pod-met) - objekt (pred-met) u pravcu razumijevanja iskustva (= zbilje) kao specifičnih suodnosnih funkcija (psihofizičke sile ${ }^{61}$ koje se postvaruju i razgrađuju prema obrascu prijenosa karmičke energije) koje obrazuju individualni tok iskustva (ne in-dividuum) ${ }^{62}$ barem na razini iskaza »zaustavljeno« oblikovanjem primjerenih shematskih »tablica« poput skandhe, àyatane ili dhätu, tvorci abhidharme dodatno su »razgradili« potonje iskaze na još elementarnije događaje iskustva (dharme) koje su metodološki predstavili odnosom citta-cetasika (ili caitta u inačici sarvāstivāde), kako smo netom mogli vidjeti. Takav opis iskustva predstavljao je za abhidharmīke najprimjereniji ili apsolutni jezični iskaz koji posve korespondira samoj stvari iskustva kada se ono rastavi na »sastavne dijelove«. Otuda se u kasnijim raspravama pozicija abhidharme tumači kao iskaz ili učenje iz perspektive »najviše stvarnosti« (paramatthatas, paramārthatas), tj. stvarnosti kako (uistinu) biva (yathābhūta), posve očišćeno od slučajnih, nepreciznih ili dvosmislenih iskaza. Premda je istina da najstariji slojevi $a b-$ hidharme predstavljaju egzegezu Buddhina učenja, kasnija je tradicija abhidharme sve više "zaboravljala« svoja tekstualna ishodišta i na određeni način počela se baviti samom sobom, tj. nastojanjem da se dalje usavršava (kako jezično tako i doktrinarno) jednom usvojeni eksplanatorni diskurs. To je posebno vrijedilo za školu sarvāstivāda.

Kako bilo, analiza iskustva rane abhidharme zaustavila se na određenom broju najelementarnijih njegovih »tipova« putem kojih se ono na iscrpan način može opisati i objasniti, tj. na dharmama. Prirodno se postavlja pitanje kakav »ontološki«, ako uopće, status imaju dharme? Mogli smo vidjeti da Buddha inzistira da je priroda svakog događaja ili fenomena, pa čak i onog najelementarnijeg, netrajnost, nesupstancijalnost i uvezanost u patnju i da je fenomen samo toliko fenomen što se pojavljuje u okolnostima drugih fenomena. Izvan tih odnosa nemoguće je govoriti o nekom fenomenu po sebi. Zahvaćanje u taj suodnos među fenomenima predstavlja stvarno znanje koje Buddha naziva pratītya-samutpāda ili idampratyayatā (dosl. »ta-uvjetovanost«). Stoga na pitanje što je dharma (ili dharme), Buddha je mogao odgovoriti jedino: »tko vidi dhammu vidi paticca-samuppādu; tko vidi pațicca-samuppādu vidi dhammu«. Pitanje »što« dhamme smisleno je jedino kao pitanje »kako« dhamme i takvu fenomenološku »poziciju« čini se prihvaća ili, bolje kazano, nasljeđuje i rana abhidharma.

Otuda je razumljivo da rani tekstovi abhidharme »definiraju « dharme na krajnje opisan, upravo fenomenološki način i da je stoga tu posve odsutan logički tip definicije prema načelu višeg rodnog pojma (kojega kod tako fenomenološki shvaćenih dharmi ne može ni biti) i specifične razlike. »Definicije« dharmi redovito se pojavljuju uz prethodna pitanja koja započinju s »kako«, »na koji način«, »koliko», »koji« itd., i »odredbe« koje slijede krajnje su deskriptivne, pri čemu se ni u kojem slučaju ne produbljuje (ontološko) značenje dharmi, nego ih se promatra u kontekstu njihova su-pojavljivanja s drugim 
dharmama, tj. očito prema obrascu pratītya-samutpāde: »po uvjetu A, B (C, $\mathrm{D}, \ldots) \ll$ ili gdje A, tu B $(\mathrm{C}, \mathrm{D}, \ldots)$. Evo primjera:

»Koja (od dharmi) je u tom trenutku ${ }^{63}$ osjećaj? Ona koja je u tom trenutku mentalni čimbenik radost i mentalni čimbenik ugoda/sreća nastala iz su-dodira s elementom razumske svijesti koji je pripadan tom (osjećaju), osjetna radost i ugoda/sreća nastala iz su-dodira s mišlju, osjećaj radosti i ugode/sreće nastao iz su-dodira s mišlju - to je u tom trenutku osjećaj. $\ll^{64}$

koji se više ne vraća« (anāgāmìmaggacittam, tj. onoga koji živi posljednje rođenje) i »svijest puta arahatstva« (arahattamaggacitta, tj. onoga koji neposredno dokončava sve preostale i svevrsne zaprjeke oslobođenju). Sveukupno, četiri tipa svijesti. »Ulaženje u tok« označuje nepovratni ulaz na put oslobođenja, tj. na »plemeniti osmerostruki put«. Ti se tipovi svijesti razvijaju i postižu metodom razvijanja ili kultiviranja uvida (vipassanābhāvanāa) kojom se osnažuje sposobnost »mudrosti« (pañ̃a $\bar{a}$. Tek ovi tipovi svijesti jasno razabiru istinsko značenje i smisao osnovnog Buddhina učenja o tri karakteristike svake egzistencije (tilakkhana), netrajnost (anicca), nesupstancijalnost (anattā) i uvezanost u patnju (dukkha).

46

Četiri odgovarajuće rezultirajuće odnosno »dozrijevajuće « (phala) svijesti u istom »kognitivnom« nizu. Dakle, sveukupno osam tipova svijesti nadsvjetovnoga područja.

47

Osim svijesti (citta) i mentalnih fenomena (cetasika) u tu najvišu (odnosno najelementarniju) kategoriju stvarnosti abhidhamme pripadaju i tvarni aspekt iskustva (rüpa) i nibbāna. Usp. B. Bodhi, Abhidhammattha sangaha, I. 2.: tattha vutt'ābhidhammatthā catudhā paramatthato cittam cetasikam rupaim nibbānam iti sabbathā (»stvari abhidhamme o kojima se govori u njoj sveukupno je četiri sa stajališta krajnje stvarnosti: svijest, mentalni fenomeni, tvarni aspekt iskustva i nibbāna«).

48

Usp. Atthasālin̄̄, Edward Müller (ur.), Pāli Text Society, London 1897., str. 67.

49

Abhdhammattha sangaha, II. 1. ekuppādanirodhā ca ekālambanavatthukā cetoyuttā dvipañ̃̄āsa dhammā cetasikā matā (»pedeset $\mathrm{i}$ dvije dhamme združene sa sviješću koje nastaju i nestaju zajedno /sa sviješću/ i koje imaju istu podršku i osnovu /kao i svijest/ znane su kao cetasike«). »Podrška« (älambana) i »osnova« (vatthuka) u ovome kontekstu označuju istu kognitivnu »situaciju « u kojoj participiraju odgovarajući tip citte i odgovarajuće cetasike, tj. isti kognitivni niz (khana, »trenutak«) i isto područje (avacara, bhümi) njihova očitovanja. Na osjetilnom (kāma) i oblikovnom (rūpa) području citta i cetasika imaju istu fizičku osnovu (odgovarajući osjetilni organ odnosno »srce-osnova«).
50

Dodir (phassa), osjećaj (vedanā), zamjedba (sañ̃̃a), voljni element (cetanāa), jednosmjernost/usredotočenost (ekaggatā), sposobnost (mentalnog) života (jīvitindriya) i pažnja (manasikāra). Sveukupno, sedam cetasika. Sposobnost (mentalnog) življenja (jīvitindriya) jest cetasika koja vrši funkciju združivanja i održavanja svih mentalnih faktora koji obrazuju odgovarajući kognitivni trenutak. Tih sedam »općih « cetasika vrši najelementarnije kognitivne funkcije i stoga se pojavljuju u svakom tipu svijesti. Bez njih svijest uopće ne bi mogla zahvatiti svoj predmet.

\section{1}

Misaono zahvaćanje (vitakka), misaono održavanje (vicāra), odluka/odlučnost (adhimokkha), bodrost/»energija« (viriya), radost (pīti) i riješenost/voljnost (npr. za djelovanje) (chanda). Sveukupno, šest cetasika. One se javljaju samo uz neke tipove svijesti (pretežito iz područja oblikovnog zadubljenja, rūpajhāna).

52

Obmana (moha), besramnost (ahirika), nepromišljenost (anottappa), uznemirenost (uddhacca), pohlepa (lobha), (pogrešno) gledište (dițthi), samoljublje (māna), mržnja (dosa), zavist (issā), škrtost (macchariya), briga (kukkucca), lijenost (thina), tupost (middha) i sumnja (vicikicchā). Sveukupno, četrnaest cetasika.

53

Vjera (saddhā), usredotočenost/pažnja (sati), sramnost (hiri), ustezanje od lošeg činjenja (ottappa), ne-pohlepa (alobha), ne-mržnja (adosa), cjelovito održavanje ravnoteže (uma) (tatramajjhattatā), rashlađenje/umirenje (mentalnog) tijela (kāyapassaddhi), rashlađenje/umirenje svijesti (cittapassaddhi), lakoća/ »prozračnost« (mentalnog) tijela (kāyalahutā), lakoća/»prozračnost« svijesti (cittalahutāa), prilagodljivost/»fleksibilnost« (mentalnog) tijela (kāyamudutā), prilagodljivost/»fleksibilnost« svijesti (cittamudutā), okretnost/»radišnost« (mentalnog) tijela (kāyakammaññatā), okretnost/»radišnost« svijesti (cittakammaññatā), umješnost (mentalnog) tijela (kāyapāguññatā), umješnost svijesti (cittapāguñ̃natā), čestitost (mentalnog) tijela (kāyujjukatāa) i čestitost svijesti (cittujjukatā). Sveukupno devetnaest cetasika koje se nazivaju »općim blistavim« (sobhanasādhārana) cetasikama. Pod (mentalnim) tijelom (kāya) shvaćaju se osjetil- 
Osnovnu intenciju rane (kanonske) abhidharme mogli bismo stoga raščlaniti u nekoliko točaka:

1.) Polazeći od činjenice da je Buddha svoje učenje izložio u dva osnovna diskursa, posredan (kada upreže metafore, poredbe, aluzije, i druge »neprecizne« strategije poučavanja, imajući u vidu kontekst i mentalna, afektivna i druga svojstva sugovornika) i neposredan, kada učenje razlaže u primjerenim »tehničkim《 terminima (skandha, āyatana, dhātu, pratītyasamutpāda itd.), abhidharmīke su preuzele i dalje razradile ovaj drugi tip diskursa nastojeći prezentirati Buddhino učenje u čistim ili pročišćenim kategorijama koje korespondiraju sa samom stvari (iskustva). Ta se »skolastička« intencija mogla korijeniti u gore navedenom Buddhinom razlikovanju između njegovih govora koji imaju neposredno značenje (nïtattha) i onih koji imaju posredno značenje, tj. čije značenje se tek treba izvesti (neyyattha).

2.) Buddhin jednaki otklon od naivnog »empirijskog« realizma i metafizičkog mišljenja u pravcu jedne fenomenologije iskustva predstavlja samorazumljivo »doktrinarno« polazište za izgradnju sustava abhidharme. Razgradnja relacije subjekt-objekt u svim njezinim (naivno realističkim i metafizičkim) inačicama u ranoj abhidharmi rezultirala je prikazom jedne »totalističke« mape mogućeg iskustva analiziranog na najelementarnije fenomenološke »događaje« (dharma), gdje se više ne može govoriti o relaciji subjekt-objekt, nego jedino o »unutarnjem«/»mentalnom《 (citta, cetasike) $\mathrm{i} »$ vanjskom «/»tvarnom《 (rüpa) aspektu konstituiranja iskustva, razlika koja je ovdje očito provedena jedino analize radi. Riječima komentatora Buddhaghose: »Postoji put (spoznaja, konstituiranje iskustva), ali na njemu putnika (spoznavatelja, subjekta) nema.«

3.) Kako se moglo vidjeti na primjerima »definicije« ili opisa dharmi, u ranoj je abhidharmi posve odsutna njihova logička definicija koja bi prirodno mogla implicirati njihovo određeno metafizičko ili čak ontološko razumijevanje. Odredba dharmi stoga ovdje ne objelodanjuje njihov možebitni egzistencijalni »status«, nego se one promatraju isključivo u kontekstu dane fenomenološke situacije u kojoj s drugim dharmama su-učestvuju. Stoga, u ranoj abhidharmi, čini se, dharme ne korespondiraju ni s čim objektivnim (»po sebi«), što bi impliciralo metafizičku relaciju između fenomena (dharma) i njezine »vlastite biti« (svabhāva) ili supstancije (dravya). Strogo govoreći, analiza iskustva na dharme provedena je jedino u svrhu primjerenog (jezičnog) objašnjenja iskustva na tragu Buddhinih uvida, a ne radi pronalaženja njegova konačnog (metafizičkog) uporišta, što bi Buddhino učenje svelo na jedan tip metafizičkog pluralizma ili čak atomizma. Metafizičkom terminologijom moglo bi se možda reći da je »supstancija « dharme njezina funkcija ili funkcije koje vrši u iskustvenom toku. Izvan te funkcionalnosti ona ne posjeduje nikakvu zasebnu zbiljnost. Zbilja se ne može svesti ni na kakve konstituense u apsolutnom smislu, pa čak ni kada se ova pokuša raščlaniti na najelementarnije »događaje«. Fenomenološka priroda tih »događaja« jednostavno izmiče bilo kakvom pokušaju formalno logičkog i metafizičkog određenja.

4.) Ranu abhidharmu stoga možemo okarakterizirati kao jednu analitičku znanost koja istražuje unutarnje mehanizme oblikovanja svjesnih doživljaja (citta-cetasika). Ta je znanost posve praktična i introspektivna (kontemplativna), pri čemu istraživanje tih mehanizama ima za cilj ostvariti transformaciju svijesti u skladu s općim idealom buddhističke prakse. Metoda prikazivanja tipova svijesti i njihovih neprestanih transformacija 
na raznim fenomenološkim područjima (avacara, bhümi) ili »uzdizanje« svijesti iz područja osjetilnosti do »nadsvjetskog « područja reflektira zapravo unutarnju dinamiku buddhističke kontemplacije i njezinih sukce-

ne sposobnosti, zamjedba (sañña), osjećaj (vedanā) i voljni kompleks (cetanā) uzet zajedno, a gdjekad se ubraja i intencionalnost (manasikāra)

54

Ispravan govor (sammāvācā), ispravno djelovanje (sammākammanta) i ispravan način življenja (sammājīva). Sveukupno, tri cetasike. Nazivaju se »cetasike uzdržavanja« zato što one odvraćaju od lošeg ponašanja (u govoru, djelovanju i načinu življenja). Shvaćaju se kao podvrsta blistavih cetasika.

55

Sućutnost (karuñā) i dobrohotnost (muditā). Sveukupno, dvije cetasike. To su cetasike upravljene prema svim živim bićima i potencijalno su neograničene (appamañ̃̃ā) u svom dosegu. I one se shvaćaju kao podvrste blistavih cetasika. U mahāyānskom buddhizmu karuñā će uz mudrost (prajñā) postati osnovno »transcendentalno« svojstvo puta bodhisattve. No već i u theravādskoj abhidhammi karunā ima svojstvo otklanjanja patnje u drugih bića. Usp. B. Bodhi, Abhidhammattha sangaha, str. 90 .

56

Sposobnost mudrosti (pañ̃indriya), jedna cetasika. Sposobnost mudrosti prodire $\mathrm{u} \gg$ »stvari kako bivaju« (yathābhūtam) i isključivo se pojavljuje uz tipove svijesti na »nadsvjetskom području« (lokuttarāvacara). O fenomenološkoj vrijednosti svih navedenih cetasika usp. B. Bodhi, Abhidhammattha sangaha, str. 77-90.

57

Usp. analizu Rūpa kaṇde Dhammasamgaṇi, gore.

58

Nibbāni je u priručniku posvećeno relativno kratko razmatranje s obzirom na to da se o »njoj« nema što fenomenološki reći, izuzev da predstavlja »odvajanje od žudnje« (tañhāya nikkhantattā nibbānan ti pavuccati). Formalno, nibbāna transcendira prirodnu svijest odnosno tipove svijesti iz prvih triju područja (kāma, rūpa i arūpa) i pojavljuje se kao "predmet« četiriju »putova i plodova« »nadsvjetskog« (lokuttara) područja svijesti (nibbānaì pana lokuttarasankhātam catumaggañānena sacchikātabbaì maggaphalānam àlambanabhūtaì). Premda je po svojoj prirodi (sabhāvato) jedna ili jednostruka (ekavidham), prema svojim različitim »aspektima« (ākārabhedena) može se označiti kao praznina (suñ̃̃atā), bez oznake (»atributa«, animitta) i lišena žudnje (appanihita). $\mathrm{U}$ fenomenološkom ambijentu theravādske abhidhamme ta se tri aspekta nibbāne moraju shvatiti kao oznake neuvezanosti nibbāne u tri korijenske nepovoljnosti (akusala hetu), naime pohlepu (lobha), mržnju/»averziju« (dosa) i obmanu (moha) koje se u ovoj ili onoj mjeri korijene u svakom tipu svijesti izuzev one u arahata (probuđenog). Konačno, shvaća li theravāda nibbānu kao neko »nešto« ili pak kao puki učinak sustavno kultiviranog »puta pročišćenja« (visuddhimagga) skiciranog u osnovnim potezima u abhidhammi, ostaje ipak nerazjašnjeno i skriveno $u$ »nepreciznim« pjesničkim formulacijama: »Veliki mudraci, oslobođeni od žudnje, kazuju da je nibbāna mjesto/područje/stanje/oznaka koje je besmrtno, beskrajno, neuvjetovano/nesloženo i nenadmašno " (padam accutam accantam asankkhatam anuttaram nibbānam iti bhāsanti vānamuttā mahesayo). Usp. B. Bodhi, Abhidhammattha sangaha, VI. 30-32.

59

Jedna citta (u osamdeset devet osnovnih »tipova «), pedeset dvije cetasike, dvadeset osam rūpa i »jedna« nibbāna.

60

Usp. A. K. Warder, Indian Buddhism, str. 213-215; E. Frauwallner, Studies in Abhidharma literature and the origins of Buddhist philosophical systems, str. 14-20.

61

Zanimljivo je da se u zrelom razdoblju škole sarvāstivāda cetasike odnosno caitte shvaćaju kao »podvrste« saṃskāra koje Ščerbatski sasvim primjereno prevodi kao »sile« (forces). Usp. Fjodor Ščerbatski, Ranobuddhistička dharma, preveo Goran Kardaš, Demetra, Zagreb 2005., str. 26ff.

62

Rane buddhističke škole silno su se trudile kako racionalno usuglasiti s jedne strane činjenicu da ne postoji nositelj individualnog iskustva (dakle, u strogom smislu ne postoji individua, osoba) i s druge, očevidnu činjenicu da »moj« tok bivanja ne preteže $\mathrm{u} » t v o j \ll$, pa otuda proizlazi da ipak postoji neki principium individuationis. Buddha je takve i slične metafizičke »dvojbe« redovito pripisivao sklonosti dogmatskoga (ditthi) uma da zbilju promatra u kategorijama »ili jest ili nije« kojoj je suprotstavljao "put iz središta« (= pratītya-samutpāda). Ne ulazeći ovdje u eksplikaciju racionalnog rješenja toga problema koje su ponudile pojedine ranobuddhističke škole, možemo samo navesti da je theravāda $\mathrm{u}$ tu svrhu oblikovala koncepciju bhavange (»životni kontinuum« koji održava sve procese iskustva na okupu), sarvāstivāda je ponudila silno zamršenu koncepciju prāpti (»posje- 
sivnih postignuća (phala) koji idealno vode nirvāṇi. Stoga možemo zaključiti da je intencija rane abhidharme racionalno i sustavno prikazati osnovna događanja i postignuća na ključnim postajama te prakse, a ne prikaz svakog mogućeg iskustva, tj. iskustva koje nije povezano s tom praksom, premda se još prema Buddhinom uvidu poznavanjem obrazaca koji grade iskustvo (= pratītya-samutpāda) može objasniti i rastumačiti svaki tip iskustva i svaka pojava općenito.

\title{
Goran Kardaš
}

\section{Content, Methodology and Intention of Presentation of the Buddha's Teaching in Terms of Canonical Abhidharma}

\begin{abstract}
The paper explores the type of discourse of the so-called canonical Abhidharma as the earliest systematic presentation of Buddha's teaching. Certain located canonical sütras (Buddha's discourses) might served as a doctrinal starting point for constructing the system of Abhidharma as well as its methodology of presentation that could be rooted in Buddha's differentiation between direct (nitattha) and indirect (neyyattha) types of discourse. In continuation of the article, we proceed to analyze content and method of presentation of the canonical Abhidharma within the Theravāda Buddhist school as it was carried out in two of their classical works: Dhammasamgani and Abhidhammatthasangaha. In these works, an analysis of reality as primary psycho-physical data (dharmas) is carried out consistently. It is furthermore shown that such an analysis of reality avoids an ontological question about the existential status of dharmas that, on the contrary, should be understood as the phenomenological description of elementary psycho-physical functions that shape experience or 'types' of consciousness (citta). The article concludes with the elaboration of possible reasons (intentions) for constructing the system of canonical Abhidharma.
\end{abstract}

\section{Key words}

abhidharma, Buddha, dharma, phenomenology of experience, theravāda, types of consciousness

dovanje«), dok je škola sautrāntika činjenicu kontinuuma iskustva tumačila koncepcijom »sjemena« (bija), svojevrsnih »paketića« karmičke energije koji se prenose i ostvaruju na istom području ili dimenziji iskustva, a koja se (konvencionalno) imenuje »individuom« (pudgala).

63

U ovom se kontekstu »u tom trenutku« (tasmim samaye) odnosi na osjetilno područje svijesti (kāmāvacaracitta).
64

Katamā tasmim samaye vedanā hoti? Yam tasmim samaye tajjāmanoviñ̃̄ānadhātusamphassajam cetasikam sātam cetasikam sukham cetosamphassajam sātam sukham vedayitam cetosamphassajā sātā sukhā vedanā-ayam tasmim samaye vedanā hoti. Vidi: Dhammasamgani, Edward Müller (ur.), Pali Text Society, London 1885., I, 2. 